\title{
THE APPLICATION OF MARKET APPEAL-ROBUSTICITY MATRIX: A CASE STUDY OF THE ARCHAEOLOGICAL HERITAGE OF LENGGONG VALLEY, PERAK, MALAYSIA
}

\author{
Mat Stafa RAPIDAH ${ }^{*}$ \\ School of Environmental and Natural Resources Sciences, Faculty of Science and Technology, \\ University Kebangsaan Malaysia, 43600 UKM Bangi, Malaysia, e-mail: rapidahms@gmail.com
}

\section{Kamal Roslan MOHAMED}

School of Environmental and Natural Resources Sciences, Faculty of Science and Technology, University Kebangsaan Malaysia (UKM), 4360o UKM Bangi, Malaysia, e-mail: kamal@ukm.edu.my

\section{Che Aziz ALI}

School of Environmental and Natural Resources Sciences, Faculty of Science and Technology, University Kebangsaan Malaysia, 43600 UKM Bangi, Malaysia, e-mail: che@ukm.edu.my

\section{Mohd Shafeea LEMAN}

School of Environmental and Natural Resources Sciences, Faculty of Science and Technology, University Kebangsaan Malaysia, 4360o UKM Bangi, Malaysia, e-mail: shafeea@ukm.edu.my

\section{Mokhtar SAIDIN}

Centre for Global Archaeological Research, University Sains Malaysia, 11800 Pulau Pinang, Malaysia, e-mail: mmokh@usm.my

Citation: Rapidah, M.S., Mohamed, K.R., Ali, C.A., Leman, M. S., \& Saidin M. (2018). THE APPLICATION OF MARKET APPEAL-ROBUSTICITY MATRIX: A CASE STUDY OF THE ARCHAEOLOGICAL HERITAGE OF LENGGONG VALLEY, PERAK, MALAYSIA. GeoJournal of Tourism and Geosites, 23(3), 702-718. https://doi.org/10.30892/gtg.23307-321

\begin{abstract}
As one of the important World Heritage Site - the Archaeological Heritage of Lenggong Valley, Malaysia, cultural tourism should be promoted along with heritage tourism by developing a number of linked sites as a heritage trail. For helping the development of such, this study evaluates the applicability of the market appeal-robusticity matrix on heritage tourism development, by assessing the potential for tourism in Lenggong Valley. Methods used were based on literature research, site observation and questionnaire survey. The detailed explanation on selected sites represent high and low levels of grading in terms of market appeal and robusticity, and hence suggesting different asset conservation and management options. The findings indicate the matrix is effective to evaluate the assessment of the heritage tourism potential because it instantaneously determines the importance of two major considerations for both tourism industry and heritage management-the attractiveness of the assets and its ability to cope with tourists. This assessment is essential to protect culture heritage assets through suitable legislation and framework for better informed planning decisions in the future. The distinctive features of the sites, their extent and, for the future, their conservation, will facilitate an improved appreciation of cultural heritage assets as part of the community.
\end{abstract}

\footnotetext{
* Corresponding author
} 
The Application of Market Appeal-Robusticity Matrix: A Case Study

of the Archaeological Heritage of Lenggong Valley, Perak, Malaysia

Key words: cultural tourism, Archaeological Heritage of Lenggong Valley, tourism potential, market appeal, robusticity

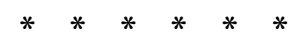

\section{INTRODUCTION}

Cultural tourism can be defined as "a form of tourism that relies on a destination's cultural heritage assets and transforms them into products that can be consumed by tourist" (du Cros \& McKercher, 2015, p. 6) and has been recognized as a special interest tourism segment by the United Nations World Tourism Organization (UNWTO) since 1976. The cultural tourism, a special interest form of tourism may be a less unfavourable and extra sustainable form of tourism (Bucurescu, 2013). It caters to the desire of tourists to learn about the history and lifestyle of a destination. It exploits both tangible and intangible cultural assets, such as the physical embodiment of cultural values in the form of historic buildings, monuments, arts and crafts, local ways of life, social customs and cultural celebrations and crafts to name a few (Li \& Lo, 2004). On the other hands, cultural landscape (Cappucci \& Zarrilli, 2008) and their relationship with environmental components and their development are topical issues in many countries since they represent a new way of building the relationship between people and nature, and can create new insights for tourism development of a territory.

Many recent studies in several regions of the world are engaged with the research theme that investigates the strong relationship between the environment and the cultural heritage (e.g Panizza \& Piacente, 2008; Alexandrowicz et al., 2009; Kavčič \& Peljhan, 2010; Bujok et al., 20015; Goemaere et al., 2015) and the relationship between geoheritage and tourism (e.g. Dowling \& Newsome, 2010; Vdovets et al., 2010; Piranha et al., 2011; Fassoulas et al., 2012; Endere \& Prado, 2014; Ólafsdóttir \& Dowling, 2014; Sellier, 2016). The importance of developing studies linking geology, geomorphology and cultural heritage can be traced in Gordon (2012); Moroni et al. (2015) and Coratza et al. (2016). According to McKercher \& du Cros (2002), the assessment of the tourism potential of a heritage asset involves not only an examination of its market appeal, but also the consideration of its ability to cope with tourists - its robusticity by using an audit model known as the market appeal-robusticity matrix (du Cros, 2001). The assessment for attractiveness includes the market appeal and product design needs, i.e. the visual appeal and setting, evidence of technical or innovative processes, tourism activity and their accessibility together with the availability of facilities and amenities. Assessing cultural heritage management should involve two major steps: examining the cultural significance of the assets and evaluating the robusticity, i.e. the assets' ability to cope with increased visitation. In addition, the assessment of aesthetic, historic, scientific, and social values as well as their rarity and representativeness is important for understanding the assets' cultural significance.

Any proposed use of the assets should be appropriate to the result of the cultural significance assessment that will determine the assets' tourism potential. In this process, market appeal assessment determines whether the heritage assets have features appealing to tourists and therefore must be correlated with a robusticity assessment that determines the degree to which visitation does not compromise the assets' cultural values (Li \& Lo, 2004). In contrast, Bucurescu (2013) claimed, while the assessment on the images and promotion of tourism potential in historical town is crucial, the assessment of their robusticity- their capacity to resist and absorb the negative impacts from tourism, is considered a secondary issue that can be solved afterwards, if some problems appear. The Lenggong Valley can be considered as a natural laboratory (Hall, 2010; Sfenthourakis \& 
Triantis, 2017) for the study of the relationship between the cultural components of the rich heritage of the archaeological, geological and geomorphological context in which they are located. Until recently, Lenggong Valley had very few economic activities and was among the least populated districts of Perak State. These activities include agriculture, carpentry, deer farming, handicrafts and fishing as small-medium industries. Starting from 2012, the Lenggong Valley has been targeted for tourism development after its inauguration as a UNESCO World Heritage Site known as the Archaeological Heritage of Lenggong Valley (AHLV), after a series of ground breaking discoveries, especially the unearthing of the illuminant Perak-Man, on top of the discovery of a meteorite impact site and numerous prehistoric tools and open workshop sites (Department of National Heritage, 2011). Therefore, efforts have been made to market the unique local heritage and activities to tourists. AHLV has rich geological and archaeological heritages which exceptionally bear witness to the long prehistoric and geological activities within this area. The AHLV is located in the northern part of Perak State, Peninsular Malaysia (Figure 1).

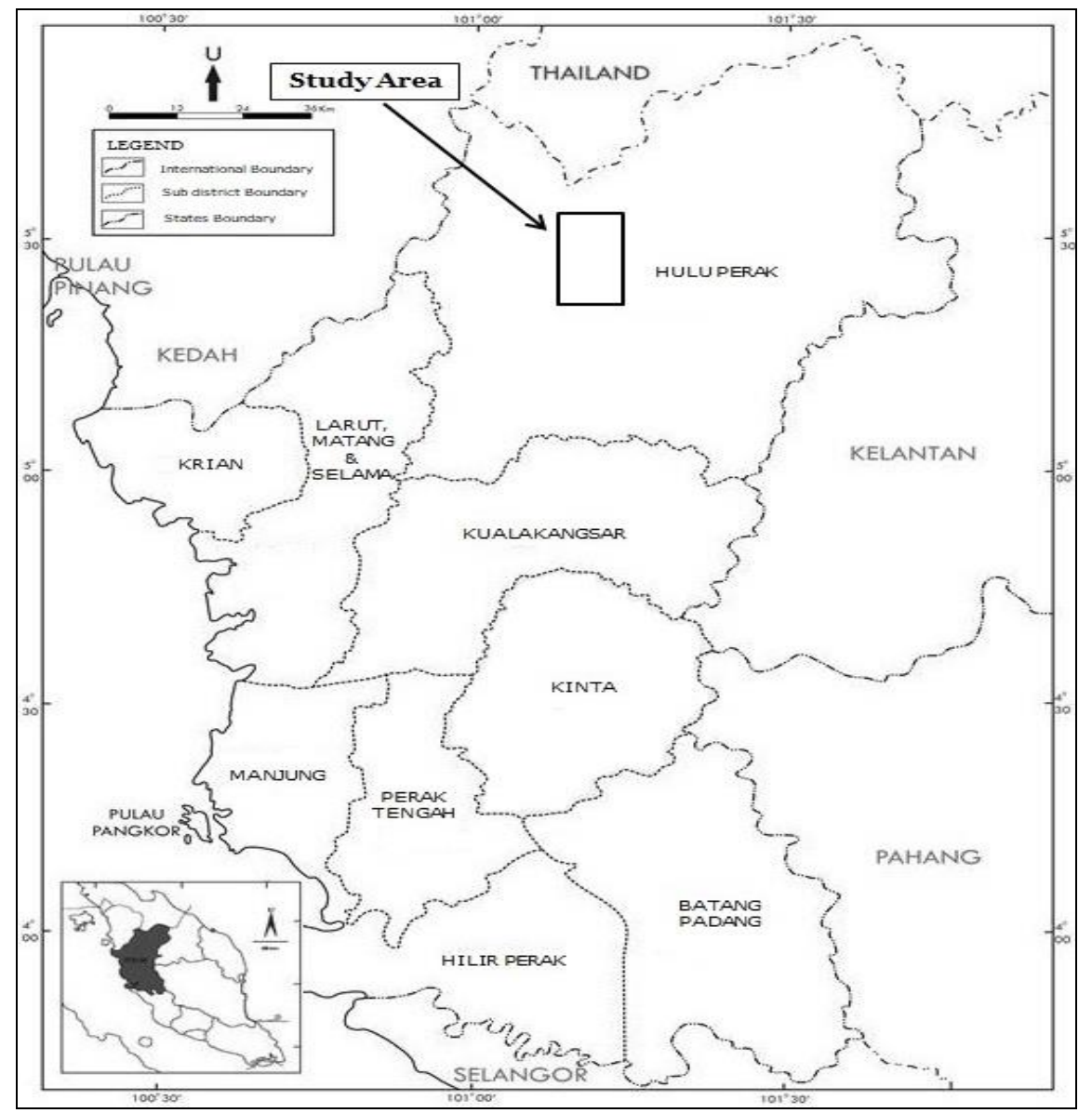

Figure 1. Location map of the study area. Lenggong Valley is located in the upper part of Perak state, Malaysia

For instance, the Department of National Heritage is responsible to initiate, coordinate and control the activities on matters relevant to the proper management of 
The Application of Market Appeal-Robusticity Matrix: A Case Study of the Archaeological Heritage of Lenggong Valley, Perak, Malaysia

this area. Meanwhile, research institutions such as the Centre for Global Archaeological Research (CGAR) from University Sains Malaysia (USM) is undertaking the work to facilitate, promote and whenever feasible, engage in research and development including scientific and educational studies within the site with local or international research institutions under the supervision of the Department of National Heritage. Research scope will be broaden and not be restricted to only archaeology but cut across an array of wide-ranging disciplines which include geotourism, climate change, habitat evolution, botanic, global tectonic and etc. The major purpose of this paper is, therefore, to evaluate the applicability of the market appeal- robusticity matrix on tourism potential assessment in the context of cultural heritage management by assessing the potential for tourism development in the AHLV. This study focuses on 12 heritage assets of AHLV (Figure 2).

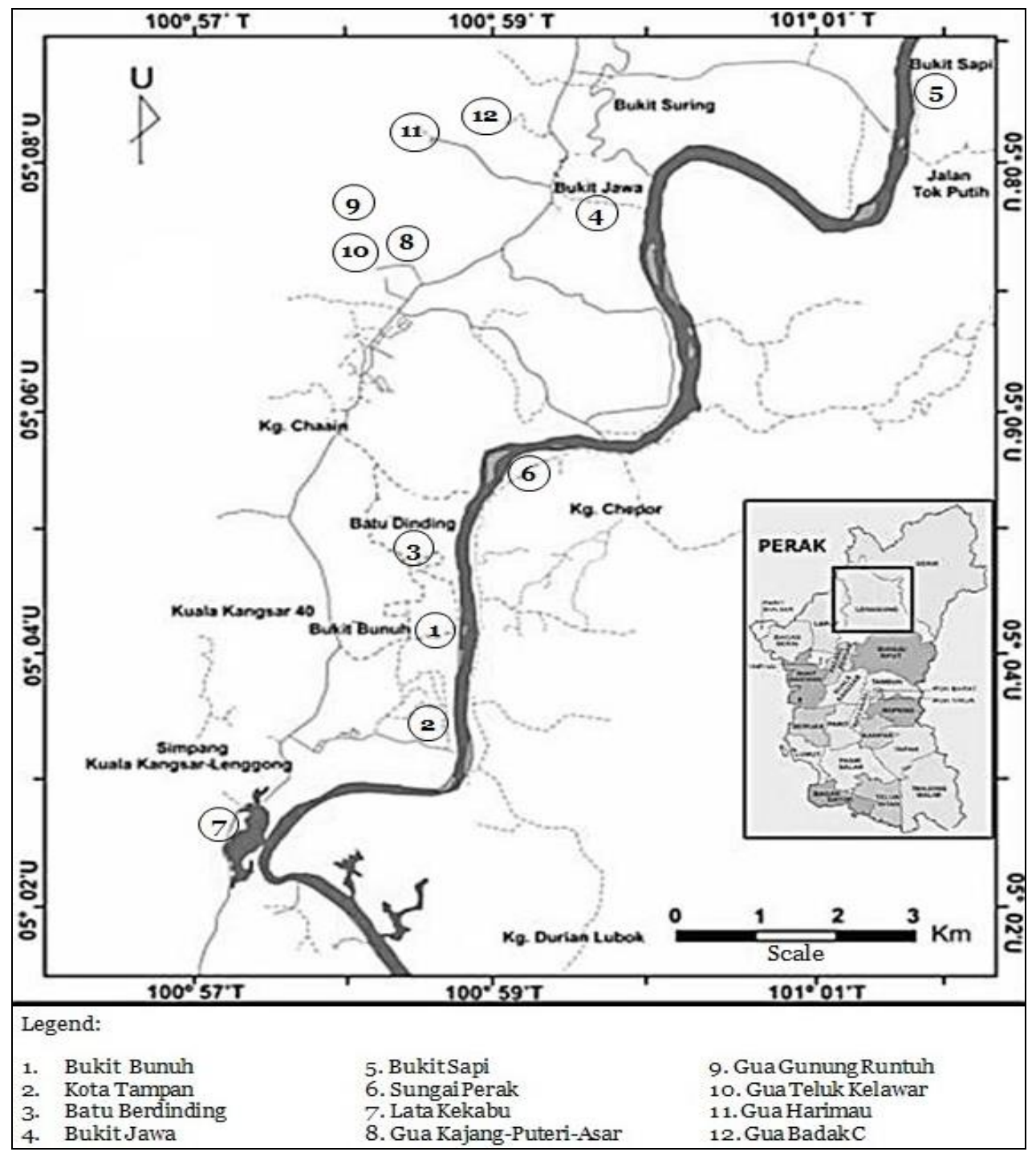

Figure 2. The heritage assets in AHLV are selected for this study Source: Dossier of Archeological Heritage of Lenggong Valley (2012) 
It is an extraordinary organically evolved cultural landscape (Cappucci \& Zarrilli, 2008) that bears evidence of a continuous human occupation from the Early Palaeolithic to the recent past. The AHLV contains a myriad of caves and one of the largest numbers of in situ Palaeolithic open sites in Southeast Asia. All these open sites are located on ancient lakeshores, the remnants of which can still be seen today. The valley also holds important record of geological events that have affected ancient prehistoric society. One of these events is the meteorite fall about 1.83 million years ago. The other is a record of a volcanic eruption of Toba in Sumatra, Indonesia approximately 74,000 years ago. These two geological events have provided important samples for scientific dating of Palaeolithic sites in the Lenggong Valley. In addition to the open sites, the AHLV contains numerous cave rock shelter sites which were occupied by the inhabitants of the valley during late Palaeolithic when both geological and climatic conditions created habitable floors in the cave. There are a total of five limestone massifs, containing cave and rock shelters within the core and buffer zones of the nominated property. Human remains and artefacts with varying dates from 13,000 to 2,000 years ago have been recovered from two cave sites of Bukit Kepala Gajah and Bukit Gua Harimau. The human remains include the Perak Man, one of the oldest most complete human skeletons in Southeast Asia which has been dated to 10,120 years ago. The other burial provides evidence of a presence at the site during Neolithic and Metal age. Perak Man is the only prehistoric evidence in the world of a congenital deformity known as Brachymesophalangia type A2. The Perak Man provides a rare insight into Palaeolithic burials, diseases, beliefs and various aspects of life at that time.

\section{METHODOLOGY}

Literature study, site observation and questionnaire survey were the three major research techniques used. Literature study consists of relevant literature to collect background information for assessing the cultural significance of the assets and investigating the carrying capacity that constrain heritage tourism (Cappucci et al., 2015) development. The sources included government research and planning documents, academic literature on Culture Heritage Management, Conservation Management Plan, Special Area Plan and tourism planning. Site observations in the study area were essential in completing the assessment process, during which the researchers recorded such information as the accessibility, the fragility of the assets, and the availability of the on-site sightseeing information, the provision of signage and tourist facilities. In many situation, site observation is the most appropriate method for data collection. The questionnaire survey was to collect on the scientific and additional values of the assets (Rapidah et al., 2016), the availability of the tourist information, and the provision of the amenities. The respondents consisted of mostly the active researchers on the AHLV as well as the students who are conducting their fieldtrip to the AHLV (including international and local students) during the site observation were carried out. The researchers applied a market appealrobusticity matrix based on du Cros's (2001) model to analyse the research data. The matrix contains a grading system of sub-indicators (see Table 1) that suggest the elements for assessing the two major indicators: a heritage asset's market appeal and robusticity. It will provide macro indicators about how assets could be managed in order to optimize the relationship between tourism and cultural heritage management (du Cross, 2001).

Of the two continua of the matrix (see Figure 3), robusticity is of most interest to heritage managers to obtain the ability of that location to cope with the possible negative effects of tourism development to the cultural values of the heritage place, while market appeal is of greatest concern to determine the level of attractiveness of the particular site and its potential to be developed and promoted to the tourism industry for its 
The Application of Market Appeal-Robusticity Matrix: A Case Study of the Archaeological Heritage of Lenggong Valley, Perak, Malaysia

representation of a heritage place's worthiness as a tourism attraction (Li \& Lo, 2004).In this study, each selected asset was assessed in detail and graded according to each subindicator (Table 1) by utilizing a scaled point system. Each sector's sub-indicators was given sixty points as the maximum possible score. Once all the grades had been assigned to all indicators in each subset, an asset could be plotted on the matrix with regard to its position in relation to either continuum. There are different implications depending on the location of the asset in the matrix. A1 and A2 represent high market appeal and high to moderate robusticity, ideal for significant tourism activity because they have features to attract tourists and can endure the use in a significant level.

Table 1. Cultural heritage tourism sub-indicators and ranking score (modified after du Cross, 2001; McKercher \& du Cros, 2002; Li \& Lo, 2004)

\begin{tabular}{|c|c|c|c|c|}
\hline \multicolumn{5}{|c|}{ Tourism sector } \\
\hline \multicolumn{5}{|c|}{ Market appeal } \\
\hline \multirow{2}{*}{1.} & \multicolumn{4}{|c|}{ Ambience and setting } \\
\hline & Excellent 5 & Good 4 & Adequate $2-3$ & Poor $\mathrm{O}$ \\
\hline \multirow{2}{*}{2.} & \multicolumn{4}{|c|}{ Well-known outside local area } \\
\hline & Quite well 4-5 & Somewhat 2-3 & Not at all $0-1$ & - \\
\hline \multirow[b]{2}{*}{3.} & \multicolumn{4}{|c|}{ National or important icon or symbol } \\
\hline & Yes $4-5$ & Has some potential 1-3 & No, nor likely to be 0 & - \\
\hline \multirow{2}{*}{$4 \cdot$} & \multicolumn{4}{|c|}{ Can tell a "good" or "interesting story" - evocative place } \\
\hline & Yes 4-5 & Has some potential 1-3 & No, nor likely to be 0 & - \\
\hline \multirow{2}{*}{5 . } & Has some aspec & to distinguish it clearl & from nearby assets or & actions \\
\hline & Excellent 5 & Good 4 & Adequate $2-3$ & Poor 0 \\
\hline \multirow{2}{*}{6.} & \multicolumn{4}{|c|}{ Appeals to special needs or uses that would also attract tourists (e.g. festivals, sports) } \\
\hline & Yes 4-5 & Has some potential 1-3 & No, nor likely to be $\mathrm{o}$ & - \\
\hline \multirow{2}{*}{$7 \cdot$} & \multicolumn{4}{|c|}{ Complements other tourism products in area/region/destination } \\
\hline & Yes 4-5 & Has some potential $1-3$ & No, nor likely to be 0 & - \\
\hline \multirow{2}{*}{8.} & \multicolumn{4}{|c|}{ Tourism activity in the region } \\
\hline & High 4-5 & Somewhat $2-3$ & Not at all $0-1$ & - \\
\hline \multirow{2}{*}{9.} & \multicolumn{4}{|c|}{ Destination associated with culture or heritage } \\
\hline & High 4-5 & Somewhat $2-3$ & Not at all $0-1$ & - \\
\hline \multicolumn{5}{|c|}{ Product design needs } \\
\hline \multirow[b]{2}{*}{10.} & \multicolumn{4}{|c|}{ Access to asset's features } \\
\hline & Access to all features $3-4$ & Limited access $1-2$ & No access allowed o & - \\
\hline \multirow[b]{2}{*}{11.} & \multicolumn{4}{|c|}{ Good transport/access to assets from population centres } \\
\hline & Access excellent 3 & Easier to reach $1-2$ & Very remote/ difficult o & - \\
\hline \multirow[b]{2}{*}{12.} & \multicolumn{4}{|c|}{ Proximity to other heritage assets/attractions } \\
\hline & Walking distance 3 & Easier to reach 1-2 & Very remote/ difficult o & - \\
\hline \multirow[b]{2}{*}{13 . } & Amenity (washrooms & , parking, pathways, re & reshments, availability & fformation) \\
\hline & Excellent 5 & Good 3-4 & Adequate 1-2 & Poor 0 \\
\hline For & he tourism sector $\mathrm{Lou}$ & appeal $=O-2 O$ Moder & ite Appeal=21-4O Hig & peal $=41-60$ \\
\hline & & Cultural heritage ma & nagement & \\
\hline & & Cultural signifi & ance & \\
\hline & Aesthetic valu & (including architectur & l value in the case of $b$ & ngs) \\
\hline 14. & High 2 & Medium 1 & Low 0 & - \\
\hline & & Histo & alue & \\
\hline 15 & High 2 & Medium 1 & Low 0 & - \\
\hline 16 & & Educationa & value & \\
\hline 10. & High 2 & Medium 1 & Low 0 & - \\
\hline 17. & & Social va & & \\
\hline $1 /$. & High 2 & Medium 1 & Low 0 & - \\
\hline
\end{tabular}


Mat Stafa RAPIDAH, Kamal Roslan MOHAMED,

Che Aziz ALI, Mohd Shafeea LEMAN, Mokhtar SAIDIN

\begin{tabular}{|c|c|c|c|c|}
\hline \multirow{2}{*}{18.} & \multicolumn{4}{|c|}{ Scientific value/Research potential } \\
\hline & High 2 & Medium 1 & Low 0 & - \\
\hline \multirow{2}{*}{19.} & \multicolumn{4}{|c|}{ Rare or common heritage asset type at the destination } \\
\hline & Unique 3 & Rare site type 2 & \multicolumn{2}{|c|}{ Less common site type 1 Common site type 0} \\
\hline \multirow{2}{*}{20.} & \multicolumn{4}{|c|}{ Representativeness (good example of type) at the destination } \\
\hline & Excellent 4 & Good 2-3 & Poor 1 & - \\
\hline \multicolumn{5}{|c|}{ Robusticity } \\
\hline \multirow{2}{*}{21.} & \multicolumn{4}{|c|}{ Fragility of the asset } \\
\hline & Not fragile 4 & Quite fragile $2-3$ & Very fragile $0-1$ & - \\
\hline \multirow{2}{*}{22.} & \multicolumn{4}{|c|}{ State of repair } \\
\hline & Excellent 4 & Good 2-3 & Fair 1 & Poor 0 \\
\hline \multirow[b]{2}{*}{23.} & \multicolumn{4}{|c|}{ Management plan or policy (Western or traditional) in place } \\
\hline & Yes 5 & In preparation $1-4$ & No o & - \\
\hline \multirow{2}{*}{24.} & \multicolumn{4}{|c|}{ Regular monitoring and maintenance } \\
\hline & Excellent 5 & Good 3-4 & Fair $1-2$ & Poor 0 \\
\hline \multirow{2}{*}{25.} & \multicolumn{4}{|c|}{ Potential for ongoing involvement and consultation of key stakeholders } \\
\hline & Excellent 5 & Good 3-4 & Adequate 1-2 & Poor $\mathrm{O}$ \\
\hline \multirow{5}{*}{26} & \multicolumn{4}{|c|}{ Possibility of negative impacts of high visitation on: } \\
\hline & \multicolumn{4}{|c|}{ (a) fabric of the asset(s) } \\
\hline & Low possibility 5 & Medium possibility $2-4$ & High possibility 1 & - \\
\hline & (b) life & yle and cultural traditio & ns of local community & \\
\hline & Low possibility 5 & Medium possibility $2-4$ & High possibility 1 & - \\
\hline \multirow{4}{*}{27.} & \multicolumn{4}{|c|}{$\begin{array}{l}\text { Possibility of modifications (as part of product development) to have negative impacts on: } \\
\text { (a) fabric of the asset(s) }\end{array}$} \\
\hline & Low possibility 5 & Medium possibility $2-4$ & High possibility 1 & - \\
\hline & \multicolumn{4}{|c|}{ (b) lifestyle and cultural traditions of local community(ies) } \\
\hline & Low possibility 5 & Medium possibility 2-4 & High possibility 1 & - \\
\hline
\end{tabular}

$\mathrm{B} 1$ and $\mathrm{B} 2$ represent high to moderate market appeal but low in robusticity so the management approach is to ensure that visitation will not damage the cultural values of the asset. Low robusticity indicates the physical fabric of the assets is fragile or that its cultural value is extremely sensitive to significant impact from incoming visitors. Tourists may show strong interest to visiting these places but, because of their fragility, they have limited ability to cope with intense use. $\mathrm{C} 1$ and $\mathrm{C} 2$ represent high to moderate robusticity but moderate market appeal. Because the assets in this category are robust, they may be able to withstand greater visitation levels than their current market appeal would suggest. Therefore the market appeal of the heritage asset should be optimised while the conservation and visitor management programmes are put in place. D1, D2 and D3 represent low market appeal signifying that the assets are unlikely to attract significant visitation unless the assets are modified to such an extent that its intrinsic values would be almost totally sacrificed (McKercher \& du Cros, 2002). These types of asset should be managed for some reasons other than tourism. The biggest challenge may be to convince asset managers about their limited appeal. By applying this grading system, the researchers hoped to achieve a comprehensive investigation of the tourism potential of the tangible heritage assets in the AHLV.

\section{RESULTS AND ANALYSIS}

The following section presents a detailed assessment of the tourism potential of three assets, out of the twelve being studied, by using the matrix. The three- Bukit Jawa site, Bukit Sapi and Gua Gunung Runtuh-are selected for presentation in this 
paper because they are the most ideal sites to be showcased to tourist and, most importantly, represent high and low levels of grading in terms of market appeal and robusticity, and hence suggesting different asset conservation and management options. The presentation of each asset follows the order of "market appeal", "product design needs", "cultural significance" and "robusticity", to show the correlation with each sub-indicator within the grading system (Table 1).

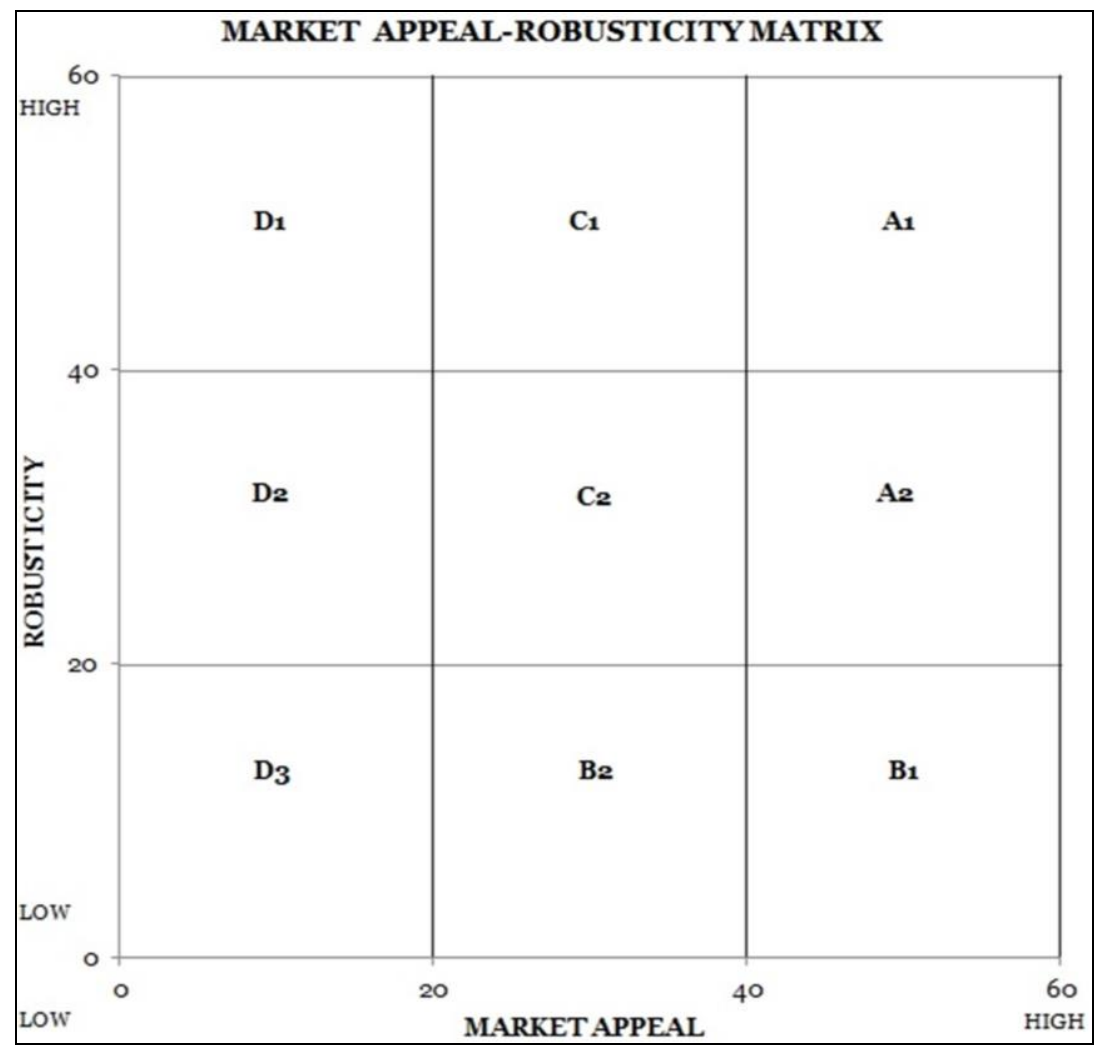

Figure 3. Matrix indicating the relationship between

the continuums of Market Appeal and Robusticity, (Source: du Cros, 2001)

\section{Bukit Jawa Site}

Bukit Jawa site (Figure 4) was discovered during a Kota Tampan palaeoenvironmental reconstruction by a team of researchers from University Sains Malaysia (USM) in 1999. Evidences of early human activities dating back 200,000 to 100,000 years ago come from the discovery of stone tools workshop that used river gravels from the ancient Perak River to produce pebble and flake tools by using anvils, cores and hammerstone, and that are crowded with thousands of debitage in the form of chunks, flakes and chips (Saidin, 1993; 2007a; 2007b; Saidin \& Jeffrey, 2007).

From the market appeal assessment indicates that this site has an excellent historical ambience with well-preserved original historical setting. The Bukit Jawa site has been interpreted as a Palaeolithic tool workshop site on the shores of an island in a palaeolake now long desiccated. The site is generally undisturbed with the cultural layer protected by a thick overburden. It is well-known outside Lenggong Valley and become 
the main attraction especially for national and international researchers. It has high potential to tell an interesting story about how the Palaeolithic population practised a similar lithic technology through time and probably settled on this site because it was a source of raw materials. This area does compliment the whole Lenggong valley as it had been determine from data that any location that is at least 72 meters above sea level and contains river gravel deposits is a potential archaeological site (Saidin, 2007a; 2007b; Saidin \& Jeffrey, 2007). In terms of product design needs, transport accessibility is not difficult and tourists are allowed access to all features of the asset. It is located close to other heritage assets of the area. In terms of amenities, it has sufficient tourist facilities such as parking, gathering space that is capable to accommodate 8-12 persons at one time and information boards. However, pathways around the existing gallery are needed.

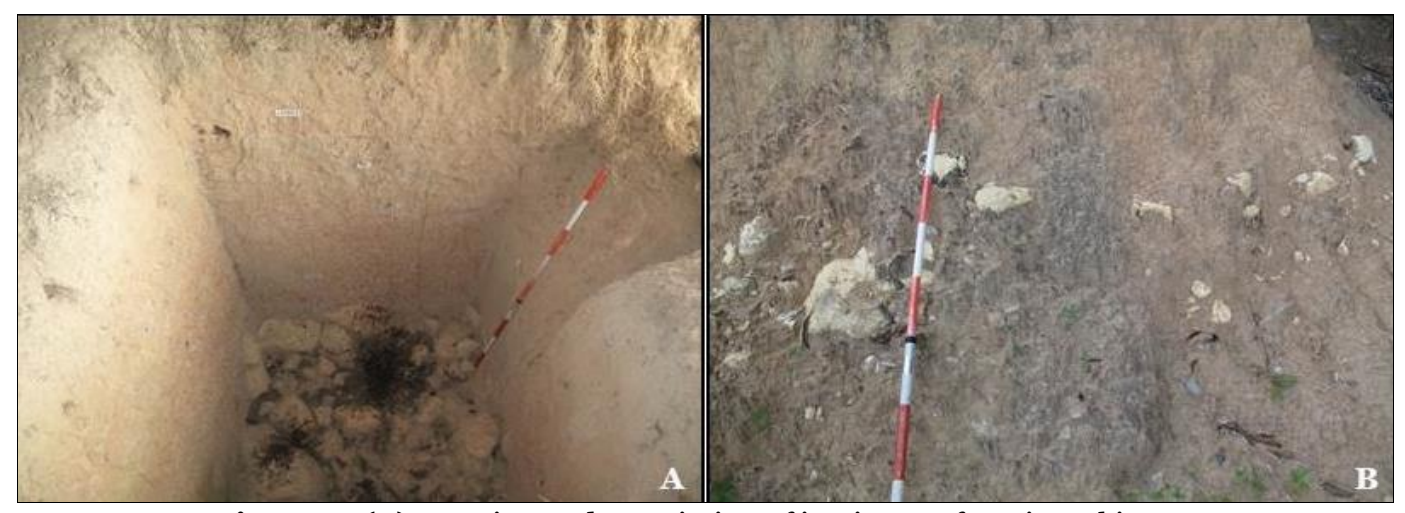

Figure 4. (A) Location and association of in-situ artefacts in Bukit Jawa,

(B) Abundant quartz as raw material in making stone tools

The cultural value assessments suggest that Bukit Jawa is high in historical, educational, social and scientific values, and has considerable aesthetic value. First, insitu Palaeolithic sites extremely rare in the world because over time, natural process and human activities would disturb the original context and erase the cultural record. Undisturbed in-situ Palaeolithic stone tool workshops are located on the shores of palaeolake and ancient river gravel beds and dated in a long chronological sequence. Second, the technique of tool making using anvils and hammer stones was similar to but not as technologically developed as that uncovered at Kota Tampan. The completed tools appear to be prototypes of Kota Tampan. Generally, they were mostly from quartz, large and crudely produced with large flakes, and reminiscent of middle Palaeolithic tools. Some are so massive as to require holding with both hands. Furthermore, the tools were cruder and there was less understanding of stone lithology, these sites had to be older than Kota Tampan. From a consideration of the stratigraphy and the morphology of the finished products, it was concluded that Bukit Jawa could be relatively dated to 200,000-100,000 years ago (Saidin, 2004; 2007a; 2007b; Saidin \& Jeffrey, 2007). In terms of robusticity, Bukit Jawa is physically not fragile and it was primarily designed for visitation, even though the gallery was only capable to accommodate 8-12 persons at one time. This site is now protected as an exposed representative of the Bukit Jawa cultural layer by the National Heritage Department and there has been management plan and regular maintenance and monitoring promises the gallery in a good state of repair. High visitation has very low negative impact on the asset as it is a very stable asset structure. The possibility of negative impact on the local lifestyle and culture tradition of local community is also very 
The Application of Market Appeal-Robusticity Matrix: A Case Study of the Archaeological Heritage of Lenggong Valley, Perak, Malaysia

limited. In general, the assessment revealed that Bukit Jawa should be placed into square "A1" in the matrix, suggesting high market appeal and high robusticity. It is the most ideal site to be showed cased to tourists because its archaeological and attractiveness values are highly significant while its fragility is not a major issue. Some development measures may be required to enhance high tourism potential such as camping site with public toilet, hall, electricity supply, real excavation sites and tools to attract primary to secondary school students, university students as well as international schools.

\section{Bukit Sapi Area}

Bukit Sapi area (Figure 5) which is located at the eastern side of the Perak River was characterised by Toba mega-colossal volcanic eruption that occurred approximately 74,000 years ago. The market appeal assessment indicates that this area has a historical ambience with a fairly well maintained original physical setting. Bukit Sapi area is probably one of another well-known area in the AHLV among national and international researchers as it is the only observable outcrop of volcanic ash deposit in the region. This area has national important icon to symbolise a wide spectrum of storytelling assets such as natural history, archaeology, culture and science. The beautiful multiple layers of white volcanic ash are the most prominent marks distinguishing from nearby heritage assets and it has some potential to attract tourists and does complement other assets in the AHLV area. The assessment of product design needs indicates that, although the area is a little remote from the other heritage assets and adequate in terms of amenities (information board and wooden pathways), it has convenient accessibility. The on-site tourist facilities such as parking, directional signage and washrooms are lacking.

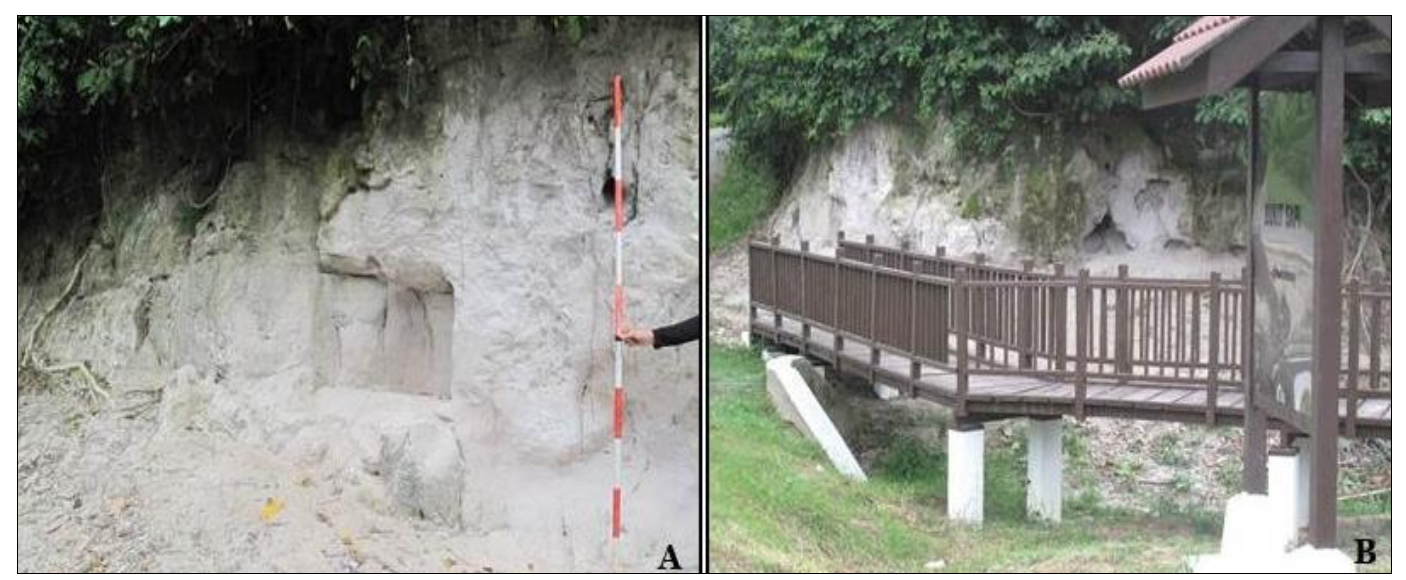

Figure 5. (A) Exposed outcrop of Toba ash deposition in Bukit Sapi area,

(B) Information board and wooden pathways are the only amenities provided

The assessment of cultural significance suggests that Bukit Sapi area has high historical, educational and scientific values, and has considerable aesthetic and social values. Its educational, historical and scientific values are significant to the catastrophic events, the Toba mega-colossal eruption dated by optically stimulated luminescence (OSL) to at least 70,000 years ago, had mingle its volcanic ash with the lithic artefacts recovered at AHLV especially at Kota Tampan and this mixture has suggested the 74,000-year date for the lithic workshop sites here (Gatti et al., 2013). The excavation work at Kota Tampan in 1987 proved to be a rare and thus significant in-situ workshop from the Palaeolithic period whose cause and date of abandonment are known (Zuraina, 1989). Its high values contribute to its 
conservation value and research potential which may help in sharing the information about the Toba mega-colossal eruption and the extinction of prehistoric community in this area. In addition, the area is exemplary in AHLV for its unique heritage asset type.

In terms of robusticity, Bukit Sapi area is quite fragile because it is primarily originated from natural phenomena - lava ash that contains of small pumice fragments, glass shards and few of crystals fragments (Zakiah, 2008). This light material is mostly in the fine sand to silt size range. Even though it is fair in state of repair, heavy visitation and modification could have medium possibility to the fabric of the asset, whilst very low possibility to the lifestyle and cultural tradition of the local community. Fortunately, as AHLV was designated as World Heritage Site, all of the area is formally protected under the UNESCO and managed by local key stakeholders such as Lenggong District Office and National Heritage Department. Its protection and conservation plan is in place and excellent access makes it easier for regular monitoring and maintenance. As a result, the assessment suggests that Bukit Sapi area should be placed in "A2" position in the matrix, suggesting moderate to high market appeal and moderate robusticity. It has been well restored for at least 74,000 years ago and has attracted national and international researchers due to its uniqueness and cultural significance. Although the area has been relatively well-known by researchers, it needs further marketing assistance to actualise the high tourism potential.
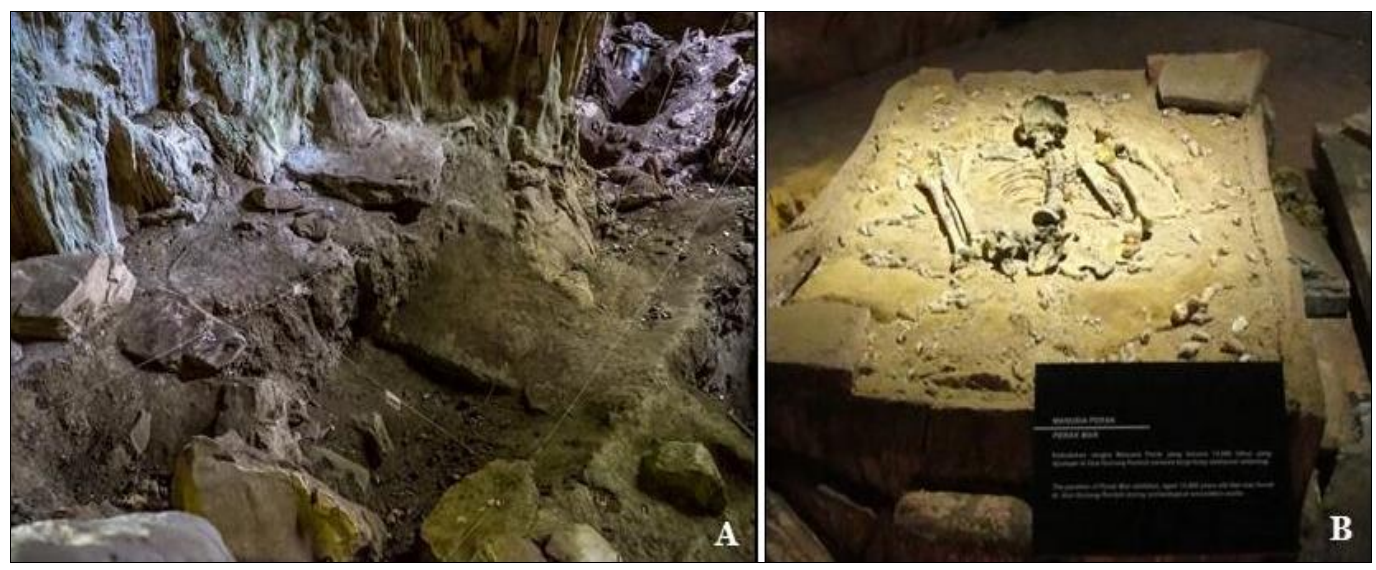

Figure 6. (A) Excavation location of Perak Man at Gua Gunung Runtuh,

(B) Preserved original skeleton of Perak Man can be seen in Lenggong Archeological Museum

\section{Gua Gunung Runtuh}

One of the most distinguished sites in AHLV is Gua Gunung Runtuh (Figure 6) which is located in Bukit Kepala Gajah Complex, approximately 10 kilometers away from Lenggong Town. This cave is part of small hamlet, Kg Gelok, where the Perak Man skeleton, a key icon in Malaysia archaeology, which remained almost intact for more than 11,000 years, was found. It has excellent historical ambiance and very well-known outside Lenggong Valley. The discovery of Perak Man is an important icon and have pinned this area in the world's scientific and archaeological map. It also can tell a good and very interesting story where Perak Man is the only prehistoric skeleton in the world born with a deformity known as Brachymesophalangia type A2 (Zuraina et al., 2005). He is also the oldest most complete skeleton in SEA. This cave does offer some potential to compliment other assets of the area such as Teluk Kelawar Cave which give an extraordinary and unique insight into the cultural habits of the prehistoric nomadic hunter-gatherer 
(Zuraina et al., 2005). With reference to product design needs, tourists are allowed limited access with guided tour to its features. Written permission to enter is needed as it is currently monitored and maintained by the National Heritage Department since the declaration of Lenggong Valley as the World Heritage Site. It is accessible by a footpath that takes half an hour to traverse and then a 15-minute of climb. The provision of complementary facilities is adequate as there are only pathways and information board about the history of the cave and some upgrading is necessary especially in terms of accessibly. The cultural significance assessment indicates that the cave is rich in historical, educational and scientific values, and has considerable aesthetic and social values. First, Gua Gunung Runtuh located approximately 124 meters above the sea level and 75 meters above surrounding secondary rainforest. There are three entrances to the cave, of which the most convenient approach is through the south entrance.

This cave has 3 chambers. The main chamber opens to the north-east. Two smaller openings to the west and south-east have been blocked by rock falls. Gua Gunung Runtuh is dry and the cave is lit by sunlight coming through the north entrance. Boulders of various sizes and fragments of stalactites and stalagmites lie scattered on the cave floor (Zuraina, 1996; Zuraina et al., 2005). Second, the Perak Man survived for such a long period of time mainly because he was buried in a well maintained original physical setting with a relatively cool and constant temperature of $24^{\circ} \mathrm{C}$ and dry slightly alkaline soil condition that was suited for bone preservation. In addition, the dryness of the cave interior has slowed down natural deterioration caused by plant growth and rock slides, and kept the population reduced. The trench from which Perak Man was excavated remains in place and has not been back-filled so as to be a record its original location (Saidin, 2005). In 2008, the Perak Man was inscribed as a National Heritage Object in the National Heritage Register (Gazette No. P.U [B] 235), followed by the site of Gua Gunung Runtuh (Gazette No. P.U [B] 494) as a National Heritage Site in 2009. This can be expected to lead to adequate management and conservation. In terms of robusticity, the condition and structure of this cave is very fragile, and has a high risk to the asset and visitors. It is also not designed for heavy visitation and can accommodate 1-25 visitors at a time. High visitation may cause negative impacts to the cave due to its fragility of coping with intense use. Fortunately, it is formally protected under the World Heritage Site law, no alteration is allowed and basic regular maintenance consists of underground trimming, trash collection and clearing of the access trail to the cave by the legal authority (National Heritage Department) promises the cave a good state of repair. In addition, the possibility of negative impacts on local way of life by visitation or modifications may not be high as the residents stay quite far. In general, Gua Gunung Runtuh should be placed in "C1" position in the matrix, signifying high robusticty and moderate to high market appeal. Physically, it is very sensitive to high visitation because of its fragility of the materials and structures. Major rock falls and cave-ins made this site unsafe for unsupervised visits. It is likely that this single heritage site will attract significant visitors as the main market only permitted for students and history buffs.

\section{OVERALL ASSESSMENT}

In addition to the detailed assessment of the three assets, Tables 2-4 are provided to show the assessed tourism potential of all the 12 heritage assets being studied-results achieved by using the same grading system. Besides, the Market Appeal-Robusticity Matrix for the heritage assets of Lenggong Valley is displayed in Figure 7. They indicate, in general, the heritage assets divided into two main groups: (1) with high market appeal and robusticity, and (2) with medium market appeal and robusticity. 
Mat Stafa RAPIDAH, Kamal Roslan MOHAMED,

Che Aziz ALI, Mohd Shafeea LEMAN, Mokhtar SAIDIN

Table 2. Results of scoring of AHLV's heritage

assets after the assessment of tourism development potential

\begin{tabular}{|c|l|c|c|}
\hline No & \multicolumn{1}{|c|}{ Site } & Market appeal & Robusticity \\
\hline 1 & Bukit Bunuh & $51(\mathrm{H})$ & $44(\mathrm{H})$ \\
\hline 2 & Kota Tampan & $41(\mathrm{H})$ & $45(\mathrm{H})$ \\
\hline 3 & Batu Berdinding & $26(\mathrm{M})$ & $35(\mathrm{M})$ \\
\hline${ }^{*} 4$ & Bukit Jawa & $51(\mathrm{H})$ & $50(\mathrm{H})$ \\
\hline${ }^{*} 5$ & Bukit Sapi & $41(\mathrm{H})$ & $40(\mathrm{H})$ \\
\hline 6 & Sungai Perak & $46(\mathrm{H})$ & $43(\mathrm{H})$ \\
\hline 7 & Lata Kekabu & $45(\mathrm{H})$ & $41(\mathrm{H})$ \\
\hline 8 & Gua Kajang-Puteri-Asar & $34(\mathrm{M})$ & $35(\mathrm{M})$ \\
\hline${ }^{*} 9$ & Gua Gunung Runtuh & $39(\mathrm{M})$ & $41(\mathrm{H})$ \\
\hline 10 & Gua Teluk Kelawar & $30(\mathrm{M})$ & $32(\mathrm{M})$ \\
\hline 11 & Gua Harimau & $31(\mathrm{M})$ & $33(\mathrm{M})$ \\
\hline 12 & Gua Badak C & $32(\mathrm{M})$ & $32(\mathrm{M})$ \\
\hline
\end{tabular}

Note: $(\mathrm{L})=$ Low; $(\mathrm{M})$ = Medium; and $(\mathrm{H})=$ High

$*=$ Heritage assets with detailed assessment in this paper

Table 3. Results of market appeal scoring of the heritage

Assets in AHLV by using the market appeal-robusticity matrix

\begin{tabular}{|c|c|c|c|c|c|c|c|c|c|c|c|c|c|c|c|}
\hline \multirow{2}{*}{ No } & \multirow{2}{*}{ Site } & \multicolumn{9}{|c|}{ Market appeal } & \multicolumn{4}{|c|}{ Product design needs } & \multirow[t]{2}{*}{ Total } \\
\hline & & $\mathbf{1}$ & 2 & 3 & 4 & 5 & 6 & 7 & 8 & 9 & 10 & 11 & 12 & 13 & \\
\hline 1. & Bukit Bunuh & 5 & 5 & 5 & 5 & 5 & 4 & 5 & 3 & 5 & 1 & 3 & 3 & 2 & 51 \\
\hline 2. & Kota Tampan & 4 & 4 & 4 & 4 & 3 & 1 & 3 & 1 & 5 & 3 & 3 & 3 & 3 & 41 \\
\hline 3. & Batu Berdinding & 3 & 2 & 3 & 3 & 2 & 1 & 1 & 1 & 3 & 4 & 1 & 1 & 1 & 26 \\
\hline 4. & Bukit Jawa & 5 & 5 & 5 & 5 & 5 & 3 & 3 & 4 & 5 & 3 & 3 & 2 & 3 & $\mathbf{5 1}$ \\
\hline 5. & Bukit Sapi & 4 & 4 & 4 & 4 & 5 & 1 & 3 & 1 & 4 & 4 & 2 & 2 & 3 & 41 \\
\hline 6. & Sungai Perak & 4 & 3 & 4 & 3 & 5 & 4 & 4 & 4 & 4 & 4 & 3 & 2 & 2 & 46 \\
\hline 7. & Lata Kekabu & 4 & 5 & 2 & 2 & 4 & 4 & 4 & 4 & 3 & 4 & 2 & 2 & 5 & 45 \\
\hline 8. & Gua Kajang-Puteri-Asar & 5 & 4 & 4 & 3 & 4 & 1 & 1 & 1 & 4 & 2 & 2 & 1 & 2 & 34 \\
\hline 9. & Gua Gunung Runtuh & 5 & 5 & 5 & 5 & 3 & 2 & 3 & 1 & 5 & 1 & 1 & 1 & 2 & 39 \\
\hline 10. & Gua Teluk Kelawar & 4 & 4 & 3 & 4 & 4 & 2 & 1 & 1 & 3 & 1 & 1 & 1 & 1 & 30 \\
\hline 11. & Gua Harimau & 4 & 3 & 3 & 3 & 3 & 2 & 3 & 1 & 3 & 2 & 1 & 1 & 2 & 31 \\
\hline 12. & Gua Badak C & 5 & 3 & 3 & 3 & 3 & 2 & 3 & 1 & 3 & 2 & 1 & 1 & 2 & 32 \\
\hline
\end{tabular}

Table 4. Results of robusticity scoring of the heritage assets in AHLV by using the market appeal-robusticity matrix

\begin{tabular}{|c|c|c|c|c|c|c|c|c|c|c|c|c|c|c|c|c|c|c|}
\hline \multirow{3}{*}{ No } & \multirow{3}{*}{ Site } & \multicolumn{7}{|c|}{ Cultural significance } & \multicolumn{9}{|c|}{ Robusticity } & \multirow[t]{3}{*}{ Total } \\
\hline & & \multirow[b]{2}{*}{14} & \multirow[b]{2}{*}{15} & \multirow{2}{*}{16} & \multirow[b]{2}{*}{17} & \multirow{2}{*}{18} & \multirow{2}{*}{19} & \multirow[b]{2}{*}{20} & \multirow[b]{2}{*}{21} & \multirow{2}{*}{22} & \multirow[b]{2}{*}{23} & \multirow[b]{2}{*}{24} & \multirow[b]{2}{*}{25} & \multicolumn{2}{|c|}{26} & \multicolumn{2}{|c|}{27} & \\
\hline & & & & & & & & & & & & & & $\mathbf{a}$ & b & $\mathbf{a}$ & $\mathbf{a}$ & \\
\hline 1. & Bukit Bunuh & 2 & 2 & 2 & 2 & 2 & 3 & 5 & 2 & 0 & 5 & 3 & 5 & 2 & 4 & 1 & 4 & 44 \\
\hline 2. & Kota Tampan & 1 & 2 & 2 & 2 & 2 & 2 & 3 & 4 & 1 & 5 & 3 & 5 & 4 & 4 & 1 & 4 & 45 \\
\hline 3. & Batu Berdinding & 1 & 1 & 2 & 1 & 2 & 2 & 3 & 4 & 1 & 1 & 1 & 3 & 3 & 4 & 2 & 4 & 35 \\
\hline 4. & Bukit Jawa & 1 & 2 & 2 & 2 & 2 & 3 & 4 & 4 & 1 & 5 & 3 & 5 & 3 & 5 & 3 & 5 & 50 \\
\hline 5. & Bukit Sapi & 1 & 2 & 2 & 1 & 2 & 3 & 4 & 2 & 1 & 2 & 3 & 4 & 2 & 4 & 2 & 5 & 40 \\
\hline 6. & Sungai Perak & 2 & 1 & 1 & 2 & 2 & 2 & 3 & 4 & 3 & 1 & 3 & 3 & 4 & 2 & 5 & 5 & 43 \\
\hline 7. & Lata Kekabu & 2 & 1 & 1 & 2 & 2 & 2 & 2 & 4 & 3 & 1 & 3 & 4 & 4 & 2 & 5 & 3 & 41 \\
\hline 8. & Gua Kajang-Puteri-Asar & 1 & 2 & 1 & 1 & 2 & 2 & 2 & 2 & 1 & 5 & 2 & 5 & 2 & 3 & 1 & 3 & 35 \\
\hline 9. & Gua Gunung Runtuh & 1 & 2 & 2 & 1 & 2 & 3 & 4 & 1 & 2 & 5 & 1 & 5 & 1 & 5 & 1 & 5 & 41 \\
\hline 10. & Gua Teluk Kelawar & 1 & 1 & 1 & 1 & 2 & 2 & 2 & 2 & 1 & 5 & 1 & 5 & 1 & 3 & 1 & 3 & 32 \\
\hline 11. & Gua Harimau & 1 & 1 & 1 & 1 & 2 & 2 & 2 & 2 & 1 & 5 & 1 & 5 & 2 & 3 & 1 & 3 & 33 \\
\hline 12. & Gua Badak C & 1 & 1 & 1 & 1 & 2 & 2 & 2 & 2 & 1 & 4 & 2 & 4 & 2 & 3 & 1 & 3 & 32 \\
\hline
\end{tabular}


The researchers put five of them into group 1 category - "A1" square, suitable to promote as a tourism attraction because archaeological and attractiveness values are highly significant while their fragility is not a major issue. For example, at Bukit Bunuh open site, a stone hand axe was recorded embedded in a suevite rock created during a meteorite impact dated to 1.83 million years ago. This discovery strongly influences current theories for the origin, migration and spread of humans through the world. Kota Tampan is the nearby open site where stone tools associated with volcanic ash from the Toba eruption. The physical appearance of these stone assemblages confirms that Kota Tampan is indeed a very rare in-situ stone tool workshop of some sophistication. They also record the cognitive processes in stone tools making. Kota Tampan may be the oldest precisely dated evidence for modern human outside Africa. Whilst the other five falls into group 2 - " $\mathrm{C} 2$ " square, suggested they have moderate market appeal and robusticity because of their physical condition as they are quite fragile and poor in accessibility. High visitation has medium-high risk to the assets and also to the visitors. Due to the fragility of the sites especially the cave structure, site hardening is necessary to increase the physical carrying capacity as well as to ensure visitors safety. For example, the construction of boardwalks, hanging pathways or canopy walk could be carried out to increase the tourism potential.

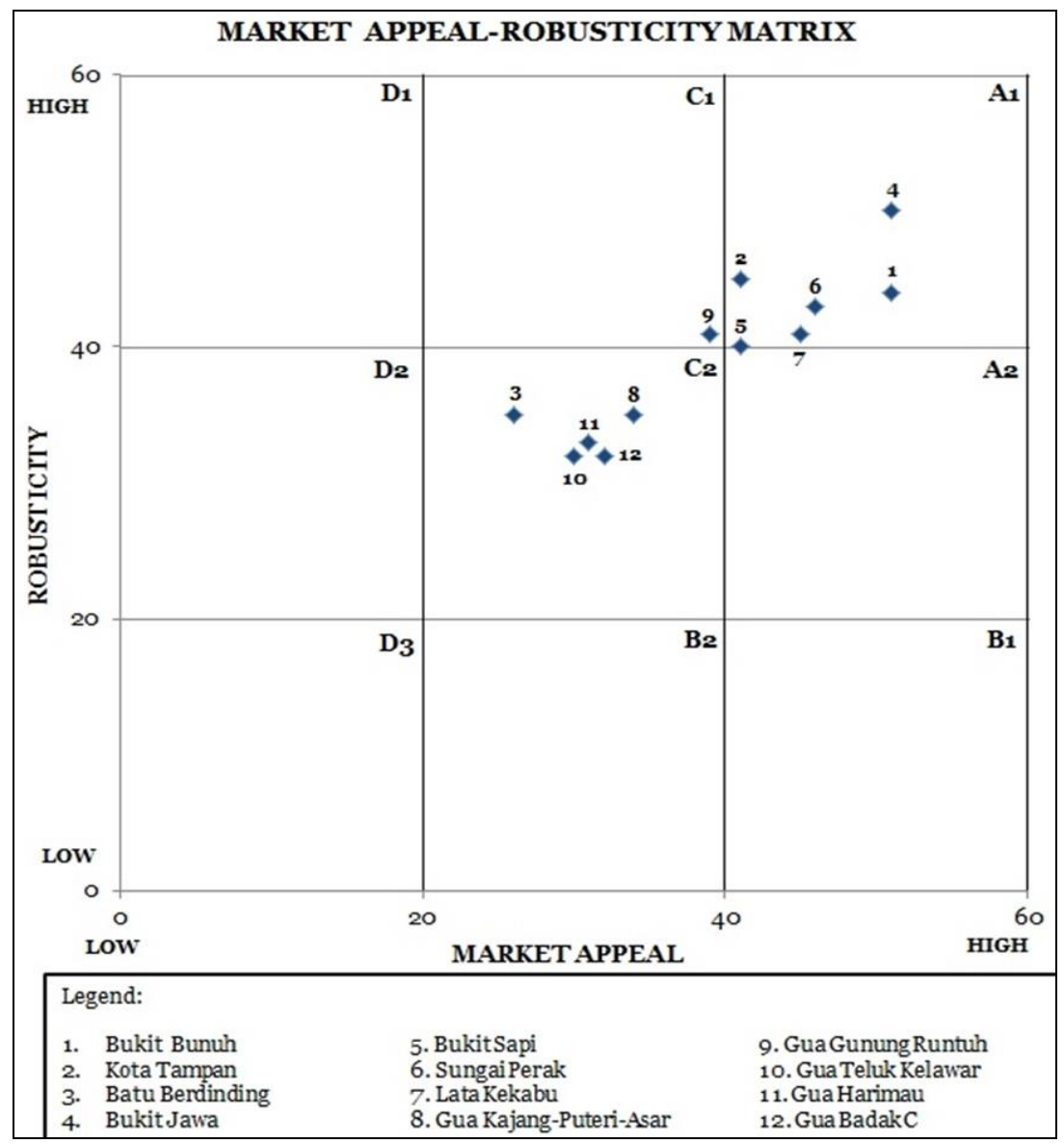

Figure 7. Market appeal - robusticity matrix for AHLV's assets 
Their market appeal must be optimised, while conservation and visitor management programmes are maintained. One of the strategies, the researchers believe to develop Lenggong Valley as a natural laboratory associated with educational tourism. Although most of them may have relatively limited tourism potential, they are highly recommended to complement with the " $\mathrm{A}$ " grade assets in order to promote their educational and cultural values as interpretation and storytelling assets in natural history, archaeology, culture and science are crucial to the tourists experience. This strategy helps enhance the iconic character of Lenggong Valley, create a heritage theme for the area, and encourage visitation to the area, in which the historical and geological site, the surrounding environment and even the neighbourhood are protected.

\section{DISCUSSION AND CONCLUSION}

Against this background, it should be highlighted that AHLV is an iconic site from the perspective of archaeological conservation which fully deserves its World Heritage Site (WHS) inscription. In a comprehensive study of the impacts of WHS listing on tourist arrivals, Hall \& Piggin (2003) revealed that while WHS inscription added value and could generate more tourist arrivals, most of the listed sites studied had been enjoying high tourist arrivals and would continue to flourish even without WHS listing. In this context, the AHLV has yet to make it into Malaysia's list of top tourism destinations although its potential of being part of an attractive tourism corridor stretching from Kuala Kangsar to Royal Belum has being recognized. As a tourism attraction, Lenggong Valley appeals to a niche market (mainly educational groups) in which interpretation and storytelling are crucial to the tourist experience. In addition, the fragility of the physical environment and artefact requires the enforcement of stringent visitor management guidelines based on the carrying capacity threshold limits.

As highlighted above, the AHLV is not suitable for mass tourism but should cater for niche market segments associated with educational tourism and heritage tourism (Vijulie et al., 2014; Cappucci et al, 2015). In this light, the carrying capacity threshold limits should be respected to protect the fragile archaeological resources and prevent mishaps and accidents to visitors. In applying the Market Appeal-Robusticity Matrix (McKercher \& du Cross, 2005), the attractiveness of the sites from the perspective of the tourist experience is evaluated by factoring in indicators such as iconic value, interpretation and potential activities. This will determine the level of attractiveness or market appeal of the particular site and its potential to be developed and promoted as a tourism attraction. For instance, the site where Perak Man was discovered (Gua Gunung Runtuh) would enjoy a high iconic value or market appeal compared to other caves. Subsequently the attractiveness of the sites is matched against the robusticity values, which are measured using indicators such as fragility, state of repair and carrying capacity. In doing so, the evaluation showed that while Gua Gunung Runtuh may be iconic in terms of market appeal, the extremely fragile interior of the cave limits its suitability in accommodating a large number of tourists at any given time without posing a threat for their safety. This means that the carrying capacity is limited unless some form of side hardening is implemented such as the construction of walkways etc.

In conclusion, the assessment of the tourism potential of a destination and the ability of that location to cope with the possible negative effects of tourism development (its robusticity) can influence the whole process of development following it, with conflict situations appearing from this imbalance. For this reason, each area must develop a clear strategy concerning the way that tourism will be developed, especially the sites with cultural heritage asset and UNESCO tourism objectives, because there is often a considerable gap 
The Application of Market Appeal-Robusticity Matrix: A Case Study of the Archaeological Heritage of Lenggong Valley, Perak, Malaysia

between the real tourism potential and the on-going cultural tourism in terms of marketing. This correct assessment of the tourism potential at a destination, especially in cultural heritage places is necessary from the very beginning as a solution for planning sustainable tourism activity and appropriate conservation operations that ensure a long time protection of the heritage. This type of assessment is the first step to be taken into account, because it can reduce the risk that the cultural heritage assets suffer from tourism. It is essential that protection is stipulate through suitable legislation, yet to be provided, in order to produce a framework for better informed planning decisions in the future. The distinctive features of the sites, their extent and, for the future, their conservation, will facilitate an improved appreciation of cultural heritage assets as part of the community.

\section{Acknowledgments}

The authors would like to thank Associate Prof. Dr. Kadderi Md Desa for his previous collaboration and supervision. The authors acknowledge anonymous reviewer for their thoughtful suggestion and comments. The authors would also like to thank Centre for Global Archaeological Research (PPAG), USM (APEX Delivery Excellent DE 2012 grant) for giving us this fund to run this research project. We also would like to appreciate the local authority (National Heritage Department (JWN), Lenggong District Council (MDL), Town and Country Planning Department (JPBD), Department of Survey and Mapping Malaysia (JUPEM) and Lenggong Archaeological Museum, local community for their great cooperation as well as national and international students who took part in answering survey questionnaires during conducting this research.

\section{REFERENCES}

Alexandrowicz, Z., Urban, J., \& Miśkiewicz, K. (2009). Geological Values of Selected Polish Properties of the UNESCO World Heritage List. Geoheritage, 1 (1), pp. 43-52.

Bucurescu, I. (2013), Tourism Potential in Historic Town: Romanian Case Studies. European Journal of Tourism, Hospitality and Recreation, 4 (2), pp. 101-130.

Bujok, P., Klempa, M., Jelinek, J., Porzer, M., \& Rodriguez Gonzalez, M. A. G. (2015). Industrial Tourism in the Context of the Industrial Heritage. GeoJournal of Tourism and Geosites, 15 (1), pp. 81-93.

Cappucci, M., \& Zarrilli, L. (2008). Cultural Landscape and National Iconography: Nation and Identity in Armenian Tourism. GeoJournal of Tourism and Geosites, 1 (1), pp. 39-47.

Cappucci, M., Pavliashvili, N., \& Zarrilli, L. (2015). New Trends in Mountain and Heritage Tourism: The Case of Upper Svaneti in the Context of Georgian Tourist Sector. GeoJournal of Tourism and Geosites, 15 (1), pp. 67-80.

Coratza, P., Gauci, R., Schembri, J., Soldati, M., \& Tonelli, C. (2016). Bridging Natural and Cultural Values of Sites with Outstanding Scenery: Evidence from Gozo, Maltese Islands. Geoheritage, 8 (1), pp. 91-103.

Dowling, R. K., \& Newsome, D. (2010). Global Geotourism Perspectives, Goodfellow Publiser Limited. Woodeaton, Oxford.

du Cros, H. (2001). A New Model to Assist in Planing for Sustainable Cultural Heritage Tourism. International Journal of Tourism Research, 8 (2), pp. 165-170.

du Cros, H., \& McKercher, B. (2015). Cultural Tourism: 2nd Edition, Routledge, Abingdon, Oxon.

Endere, M. L., \& Prado, J. L., (2014). Characterization and Valuation of Paleontological Heritage: A Perspective from Argentina. Geoheritage, 7 (2), pp. 137-145.

Fassoulas, C., Mouriki, D., Dimitriou-Nikolakis, P., \& Iliopoulos, G. (2012). Quantitative Assessment of Geotopes as an Effective Tool for Geoheritage Management. Geoheritage, 4 (3), pp. 177-193.

Gatti, E., Saidin M., Khairunnisa T., Nur Asikin R., Philip G., \& Clive O. (2013). Depositional Processes of Reworked Tephra from the Late Pleistocene Youngest Toba Tuff Deposits in the Lenggong Valley, Malaysia. Quaternary Research, 79, pp. 1-14.

Goemaere, E., Demarque, S., Dreesen, R., \& Declercq, P. Y. (2015). The Geological and Cultural Heritage of the Caledonian Stavelot-Venn Massif, Belgium. Geoheritage, 8 (3), pp. 211-233.

Gordon, J. E. (2012). Rediscovering a Sense of Wonder: Geoheritage, Geotourism and Cultural Landscape Experiences. Geoheritage, 4 (1-2), pp. 65-77.

Hall, C. M., \& Piggin, R. (2003). World Heritage Sites: Managing the Brand. In: Fyall, A., Garrod, B., and Leask, A., (eds), Managing Visitor Attractions: New Directions. Oxford: Butterworth Heinemann. 
Hall, C. M., (2010). Island Destinations: A Natural Laboratory for Tourism Introduction. Asia Pacific Journal of Tourism Research, 15 (3), pp. 245-249.

Kavčič, M., \& Peljhan, M. (2010). Geological Heritage as an Integral Part of Natural Heritage Conservation Through Its Sustainable Use in the Idrija Region (Slovenia). Geoheritage, 2 (3), pp. 137-154.

Li, Y., Lo, \& R. L. B. (2004). Applicability of the Market Appeal - Robusticity Matrix: A Case Study of Heritage Tourism. Tourism Management, 25 (6), pp. 789-800.

McKercher, B., \& du Cros, H. (2002). Cultural Tourism: The Patrnership Between Tourism and Cutural Heritage Management. New York: Haworth Press.

Moroni, A., Gnezdilova, V. V., \& Ruban, D. A. (2015). Geological Heritage in Archaeological Sites: Case Examples from Italy and Russia. Proceedings of the Geologists' Association, 126 (2), pp. 244-251.

Ólafsdóttir, R. \& Dowling, R. (2014). Geotourism and Geoparks - A Tool for Geoconservation and Rural Development in Vulnerable Environments : A Case Study from Iceland. Geoheritage, 6 (4), pp. 71-87.

Panizza, M., \& Piacente, S. (2008). Geomorphology and Cultural Heritage in Coastal Environments. Geografia Fisica e Dinamica Quaternaria, 31 (2), 205-210.

Piranha, J. M., del Lama, E. A., \& Bacci, L. C. D. (2011). Geoparks in Brazil-Strategy of Geoconservation and Development. Geoheritage, 3 (4), pp. 289-298.

Rapidah, M. S., Ali, C. A., Mohamed K. R., Leman, M. S. M., \& Saidin, M. (2016). Geological Heritage Assessment for Sustainable Development of Lenggong Valley. AIP Conference Proceedings 1784.

Saidin, M. (1993). Kajian Perbandingan Tapak Paleolitik Kampung Temelong dengan Kota Tampan dan Sumbangannya Terhadap Kebudayaan Zaman Pleistosen Akhir di Asia Tenggara. Malaysian Museums Journal, 32.

Saidin, M. (2004). Pleistocene Lithic Technology and Adaptation in Souteast Asia: New Evidence from Malaysia. Kertas Kerja Seminar 75th Aniversary of the Discovery of the First Skull of the Peking Man and 10oth Birthday of Late Prof. W.C. Pei, Beijing, 17-24 Oktober 2004.

Saidin, M. (2005). Cave Formations of Sites with Skeletal Remains in Lenggong, Perak. In: Zuraina Majid. (ed), The Perak Man and Other Prehistoric Skeletons of Malaysia. Pulau Pinang: University Sains Malaysia.

Saidin, M. (2007a). Paleolithic Adaptation: Some Criteria for Habitation Site Selection Among the Pleistocene Population in Malaysia. Archaeological Heritage of Malaysia, 1.

Saidin, M. (2007b). Kehidupan Manusia Prasejarah di Hulu Perak: Sumbangannya kepada Warisan Geologi Negara. In: Leman, M. S., Ali, C. A., and Ibrahim, K., (eds), Geological Heritage of Malaysia (Conservation of Geoheritage and Protection of Environment), LESTARI UKM, Bangi, pp. 201-210.

Saidin, M. Jeffrey, A. (2007). Sungai Perak Kuno: Sumbangannya kepada Zaman Paleolitik Malaysia. Jurnal Arkeologi Malaysia, 20.

Sellier, D. (2016). A Deductive Method for the Selection of Geomorphosites: Application to Mont Ventoux (Provence, France). Geoheritage, 8 (1), pp. 15-29.

Sfenthourakis, S., \& Triantis, K. A. (2017). The Aegean Archipelago: A Natural Laboratory of Evolution, Ecology and Civilisations. Journal of Biological Research-Thessaloniki, 24 (1), pp. 1-13.

Vdovets, M. S., Silantiev, V. V., \& Mozzherin, V. V. (2010). A National Geopark in The Republic Of Tatarstan (Russia): A Feasibility Study. Geoheritage, 2 (1), pp. 25-37.

Vijulie, I., Matei, E., irla, L., Manea, G., \& Zorzoliu, T. (2014). The Role of Archaeological Landscape Restoration in Building the Local Tourism Image: The Gumelniţa Archaeo-Park (Drăgăneşti-Olt, Romania). GeoJournal of Tourism and Geosites, 13 (1), pp. 52-65.

Zakiah, H. R. (2008). Characterization of Late Pleistocene Volcanic Ash at Lenggong Perak. B.Sc. Thesis, University of Malaya. Unpublished.

Zuraina, M. (1989). The Tampanian Problem Resolved: The Geological Evidence of a Late Pleistocene Lithic Workshop. Modern Quarternary Research in Southeast Asia, 11, pp. 71-96.

Zuraina, M. (1996). Prasejarah Malaysia: Sudahkah Zaman Gelap Menjadi Cerah?. Pulau Pinang: University Sains Malaysia.

Zuraina, M., Johan, A., Samsuddin, A. R., Nizam, A., Lim, A., Saidin, M., Jeffrey, A., \& Chia, S. (2005). GTK 1: Skeleton from Gua Teluk Kelawar, Lenggong Dated 8,400 \pm 40 BP. In: Zuraina Majid (ed), The Perak Man and Other Prehistoric Skeleton in Malaysia, Penerbit University Sains Malaysia, Penang.

*** Department of National Heritage, (2011). Archaeological Heritage of the Lenggong Valley: Nomination Dossier for Inscription on the UNESCO World Heritage List.

Submitted:

26.06.2018
Revised:

12.10.2018
Accepted and published online 16.10 .2018 